\title{
Irak - et nytt, sort hull i det internasjonale samfunnet?
}

Irak i dag er et lovløst land hvor kriminalitet og korrupsjon utgjør en integrert del av konfliktdynamikken.

Gisle Kvanvig ledet UNODC sine Irak- og Jordanprogram inntil april 2007. For tiden jobber han som rådgiver i eget foretak med spørsmål knyttet til strafferettssystemer.

Under valgkampen i oktober 2000 ytret George W. Bush: “I don't think our troops ought to be used for what's called nationbuilding". ' Den Io. september 2007 meddelte USA sin spesialutsending til Irak, Ryan Crocker, kongressen, at Irak måtte bygges fra bunnen av. Reflekterer dette et bevisst og varig skifte i USA sin utenrikspolitikk og militære doktrine? Sannsynligvis ikke. Tidligere erfaringer både USA, FN og andre har gjort seg tilsier at det sjelden er snakk å gjenreise nasjoner etter langvarige diktaturer eller krig. Det dreier seg ofte om å bygge nasjonen fra bunnen av.

Nasjonsbyggingens merittliste er brokete, men tilnærmingen i dag har lært av feilene som ble begått for eksempel i Somalia og på Balkan på 9o-tallet. ${ }^{2}$ Den blinde idealismen, ignoransen og feilskjærene som preger USA og koalisjonens arbeid i Irak innen feltene infrastruktur og konflikthåndtering er etter hvert godt beskrevet i bøker og tilgjengelige rapporter. ${ }^{3} \quad$ Mindre omtalt er den drastiske økningen i organisert kriminell virksomhet Irak har vært gjenstand for. Denne virksomheten er ansvarlig for en større del av volden i Irak enn mange er klar over, og bidrar også til å korrumpere lokale og I48 nasjonale myndigheter. Denne artikkelen ser på hva som gikk galt i implementeringen av et effektivt strafferettsystem.

\section{Konflikt, kriminalitet og korrupsjon}

I de såkalte moderne krigene som etterfulgte den kalde krigen, er grenseoppgangen mellom konflikt og organisert kriminalitet blitt mer utydelig. ${ }^{4}$ Dette har i særlig grad gjort seg gjeldende innen politisk motivert vold, slik som opprør, geriljakrig og terrorisme, som har dominert konfliktbildet på I990- og 2000-tallet. Politisk motivert vold finansieres gjerne gjennom organisert kriminell virksomhet knyttet til naturressurser som diamanter, olje, metaller og mineraler, eller smugling av våpen, mennesker og narkotika.5 Denne utviklingen gjør det vanskelig å opprettholde tydelige skiller mellom sivile, krigende og kriminelle ettersom myndigheter og enkeltpersoner trer inn og ut av disse rollene. ${ }^{6}$ I neste instans medfører dette en økning i korrupsjonsnivået. Korrupsjon i form av bestikkelser, nepotisme og kameraderi sørger for ineffektive strafferettsinstanser, medgjørlige byråkrater, grensevakter og tollere. Inntektene fra den kriminelle virksomheten brukes også til for eksempel kjøp av stemmer blant befolkingen. Resultatet 
av denne konfliktdynamikken er at staten og demokratiseringsprosesser undermineres. Sirkelen sluttes ved at myndighetenes kapasitet til å dempe konflikten forvitrer. Med denne dynamikken ser man etter hvert flere eksempler på konflikter som ikke ser ut til å ta slutt. Over tid endrer de stridende partene karakter, og i flere tilfeller er det lite annet enn retorikk igjen av det revolusjonære budskapet bevegelsene eller gruppene ble tuftet på.

I tråd med denne utviklingen har bevisstheten omkring rollen rettsstatsprinsippet og strafferettssystemet spiller i fredsbygging og stabilisering økt. I FN-resolusjon 2005/2I ECOSOC heter det at et effektivt strafferettsystem må bygge på rettsstatsprinsippet som i sin tur beskyttes av effektiviteten til strafferettsystemet. Med strafferettsystemet mener man rettsvesenet, politiet, og fengslene. Sammen skal disse instansene virke preventivt og reaktivt for å begrense og kontrollere kriminaliteten og den skaden den gjør på samfunn og individ. I de aller fleste konfliktsoner og land som har vært offer for langvarige diktaturer, står disse instansene svakt. Kofi Annan utrykte det slik da han adresserte FNs generalforsamling 2I. september 2004:

"The vulnerable lack effective recourse, while the powerful manipulate laws to retain power and accumulate wealth ..."

Dette gjelder også Irak som har vært gjenstand for en betydelig øking i organisert kriminalitet, vold og korrupsjon siden invasjonen i 2003 .

\section{Organisert kriminalitet i Irak}

Organiserte kriminelle grupper i Irak var mest sannsynlig kontrollert av Saddam
Hussein sitt regime. Hussein hevdet at den organiserte kriminaliteten var et resultat av korrupsjon, men dette er lite sannsynlig. At Hussein i det minste hadde en type overoppsyn med gruppene forklarer til en viss grad det begrensede omfanget av organisert kriminell virksomhet i Irak. For eksempel hadde Irak, inntil invasjonen i 2003, stort sett bare erfaring med begrenset cannabisbruk. Cannabis ble introdusert på 70-tallet, mens det krevdes mer enn tretti år og en invasjon før det irakiske samfunnet stiftet bekjentskap med heroin, ecstasy, kokain og illegale amfetaminer. Smuglervirksomheten til de irakiske kriminelle gruppene skjøt fart under sanksjonsregimet på 9o-tallet. I denne perioden økte etterspørselen etter luksusvarer men i liten grad narkotika. Med invasjonen forsvant restriksjonene forbundet med Saddam-regimet, lov og orden kollapset, og gruppene opererte fritt. Dermed økte smuglingen først og fremst av olje, men også av narkotika, våpen, kobber, kunstskatter, luksusartikler og piratkopier av alt fra såpe til sigaretter. En ikkeoffentliggjort undersøkelse utført av FN sitt kontor for narkotika- og kriminalitetsspørsmål (UNODC), i august 2003, slo fast at bare seks måneder etter invasjonen hadde organiserte kriminelle grupper med regionale og internasjonale forgreninger etablert seg og ekspandert sin virksomhet i Irak.

Dynamikken i oljesmuglingen som utgjør størsteparten av smuglervirksomheten i Irak illustrerer sammenhengen mellom vold, kriminalitet og korrupsjon. Irakiske oljeledninger og installasjoner saboteres og tvinger myndighetene til å øke importen av olje. Ifølge det irakiske oljedepartementet stjeles nærmere 30 prosent av 
oljen som importeres. Dette gjøres ved bestikkelser til offentlige tjenestemenn som enten justerer måleren på tankbilen eller forfalsker importdokumentene. I andre tilfeller overleveres hele tankbilen til kriminelle som selger oljen i nabolandene. I tillegg stjeles oljen direkte fra ledningene og i mer ekstreme tilfeller hele ladninger ombord i tankskip. Dette koster Irak milliarder av sårt tiltrengte dollar i året. Både opprørere og rene kriminelle er involvert i denne virksomheten. Forskjellen mellom kriminelle og politisk voldelige grupper er tydeligst når man ser på målsettingene deres og hvilke metoder de bruker. Kriminelle søker profitt der politiske grupper søker innflytelse og forandring. Politiske grupper velger midler og metoder som tiltrekker seg myndighetenes oppmerksomhet der kriminelle søker å unngå myndighetene i størst mulig grad. I Irak er det i økende grad vanskelig å se forskjell på disse gruppene ettersom kriminalitet er blitt et middel til å finansiere vold og i flere tilfeller politisk maktkamp.

Omfanget av narkotikasmuglingen i Irak er vanskelig å fastslå under de eksisterende forholdene. Irak er ikke et naturlig sted å reise rundt og stille spørsmål om narkotikasmugling og potensielle koblinger til våpenkjøp, opprørsgrupper eller terrorisme. Estimatene tyder på at narkotikasmuglingen til og gjennom Irak økte i årene 2003-2005, mens den siden 2006 har avtatt. Ironisk nok er det konflikten og den økende sekteriske inndelingen av Irak som skaper logistiske komplikasjoner for smuglerne, og dermed begrenser nytten av Irak som smuglerrute. I perioden 2003-2005 ble det rapportert om økning i heroinbeslag fra nabolandene til Irak. Jordan opplevde at beslagene tidoblet seg i volum. Det er sannsynlig at dette dreide seg om utprøving av en ny smuglerrute. Den ville gått fra Afghanistan gjennom Iran, Irak og videre til nabolandene, men det er usikkert hvilken rute stoffet ville tatt ut av Midtøsten. I 2006 styrket nabolandene grensekontrollen, samtidig som det fra Irak ble rapportert om logistikkproblemer i smuglingen på tvers av de sekteriske sonene. Selv om smuglingen gjennom Irak til andre land har avtatt, har narkotikamisbruket i Irak fortsatt å øke i omfang. Dette gjelder særlig i Sør-Irak hvor hovedsmuglerrutene inn til Iran finnes. Mangfoldet av stoffer, mengden av stoff, antallet misbrukere og prisene har økt. Dette er indikasjoner på et narkotikamarked som øker i omfang. Nylig ble det også rapportert om produksjon i form av opiumskultivering vest og sør for byen Diwaniya i Sør-Irak. Områdene kontrolleres av rivaliserende shiamilitser, og Diwaniya har vært gjenstand for harde kamper. $^{8}$

Andre former for organisert kriminalitet i Irak omfatter for eksempel kidnapping, attentater og utpressing. Disse utgjorde nærmest fra dag én etter invasjonen en hel industri. Det mest bekymringsfulle for Irak er den manglende kapasiteten til strafferettsystemet til å bekjempe kriminaliteten og den relaterte korrupsjonen.

\section{Korrupsjon i Irak}

Korrupsjonen i Irak er endemisk i den grad at den utgjør normen hos en myndighet som kanskje best kan betegnes som et sekterisk kleptokrati. Når man snakker om kapasitet innen anti-korrupsjonsarbeide, er det tale om et juridisk og institusjonelt rammeverk som eksempelvis består av et økokrim, rettsvesenet, kredittilsyn, riks- 
revisjon og interne kontrollorganer i offentlige instanser. I noen land hvor korrupsjon utgjør et særlig problem, nedsetter man egne organer for å bekjempe korrupsjonen. Uheldigvis blir det ofte med opprettelsen av organet ettersom det ofte viser seg å ikke være uavhengig verken politisk eller

\section{Ifølge en koalisjonsansatt er det} nye irakiske politiet lite annet enn en paramilitor organisasjon.

finansielt. I Irak heter hovedorganet for korrupsjonsbekjempelse The Commission on Public Integrity (CPI). Det ble stiftet av Coalition Provisional Authority (CPA) i 2004 og har vært bemerkelsesverdig effektive og uavhengige forholdene tatt $\mathrm{i}$ betraktning. Den 7. september 2007 trakk Radhi Hamza al-Radhi seg som leder fra CPI, på bakgrunn av det politiske presset han ble utsatt for særlig fra statsminister Maliki og hans regjering. Dette kan vise seg å være dødsstøtet for CPI ettersom det er Radhi sin fortjeneste at deler av CPI har opptrett politisk nøytralt. Radhi uttalte i et møte i desember 2006 at selv om han var shia, måtte han etterforske andre shiaer fordi det nå er shiaene som har makten og står for brorparten av den offentlige korrupsjonen. Hvordan ble Irak så korrupt at selve demokratiet og nasjonsbyggingsprosjektet trues?

Et hovedproblem er at Irak mangler et regelverk for offentlig ansatte og ansettelser. Dette medfører at kandidater til stillinger ansettes på bakgrunn av klan- og stammetilknytninger og ikke kompetanse. I flere tilfeller er det også oppdaget at departementene opererer med skygge- ansatte. Dette vil si at ledelsen eller ministeren oppgir uvirksomme ansatte for å øke budsjettene sine. De folkevalgte representantene er på sin side beryktet for å motta store pengegaver. Blant irakere spøkes det med at den eneste proposisjonen nasjonalforsamlingen har behandlet effektivt var den som omhandlet deres egen lønnsøkning. CPI begynte i 2004 å etterforske en korrupsjonsportefølje til en verdi av en milliard dollar. Ved utgangen av 2006 hadde verdien steget til 7,5 milliarder dollar. CPI etterforsker en serie store korrupsjonssaker. En meget betent sak omfatter Fadhila-partiet. Fadhila er et av de mindre shiapartiene og var en del av United Shia Alliance inntil mars 2007. Fadhila er spesielt aktive i Sør-Irak. Ifølge CPI og Radhi står partiet og militsen deres bak betydelig korrupsjon og tyveri av oljemidler som har gått til å finansiere våpen til militsen deres. ${ }^{9}$ Saken er ikke enestående. og illustrerer sammenhengen mellom vold, kriminalitet og politikk i konflikten i Irak. ${ }^{\text {10 }}$

Flere CPI-ansatte har blitt drept, og Radhi frykter for integriteten til organet ettersom det i økende grad blir gjenstand for politiske ansettelser. UNODC og søsterorganisasjoner i FN søkte om midler for å støtte CPI gjennom mer omfattende og spesialisert opplæring av CPI sine ansatte. Donorene viste liten interesse for forslaget, og uformelt kunne noen diplomater berette at ingen land ville sponse et anti-korrupsjonsprosjekt før oljeloven var på plass. Det står om milliarder, og selskapene og landene de representerer kan ikke risikere å tape allierte i kampen om kontrakter. CPI har makt til å etterforske korrupsjon, men må overlate bevisføringen til påtalemyndighetene når etterforskningen avsluttes. Dette betyr at CPI er avhengige av et effek- 
tivt strafferettssystem for at etterforskningen skal bære frukter i form av at korrupte embetsmenn og kvinner dømmes og fengsles. Den støtten kan de se langt etter ettersom koalisjonen og irakiske myndigheter har gjort en dårlig jobb med å etablere et slikt system.

\section{Strafferettsystemet i Irak}

Strafferettsystemet følger ulike modeller i forskjellige land, men innebærer tydelig mandater og klare avgrensinger av hvor én instans sitt virke begynner og slutter. Systemet består av tre uavhengige instanser, politi, retts- og fengselsvesen, som skal fungere sammen. Uenighet og diskusjon mellom instansene i systemet er vanlig ettersom hver enkelt av dem kan ha ulike interesser $\mathrm{i}$ enkeltsaker. Dette fordrer et robust og tydelig system. I Irak mangler dette. Et ikke uvanlig scenario i Irak er at politiet ikke vet hvordan de skal sikre åsteder og beviser. Videre mangler de relevant utstyr og kompetanse til å sammenstille og fremme en sak for retten. Tilståelser tvinges ofte frem ved bruk av tortur. Konsekvensen er at når magistraten får overlevert saken bedømmes den som for svak til å fremmes for retten. Dermed forkastes saken. Det som derimot ikke skjer er at arrestanten løslates. Han eller hun forblir i politiets forvaring uten dom. Fengsler og pågripelsesanstalter oversvømmes av innsatte og soningsforholdene blir uutholdelige. Utfordringene med å bygge et effektivt strafferettsystem i Irak er enorme.

RETTSVESENET

Saddam Hussein etterlot et kaotisk rettsvesen som i dag sliter med fragmentert lovgivning og regelverk, korrup- sjon, kapasitet og sekterisme. Det var særlig to fenomener under Saddam som underminerte rettsvesenet. Det første var de statlige sikkerhetsdomstolene. Disse domstolene var redskaper regimet undertrykket den irakiske befolkningen med. Videre delegerte Saddam juridisk autoritet til lokale stammeråd for å sementere støtte blant stammeledere. Begge tilfeller omdirigerte saker til et kvasirettslig system og underminerte rettsvesenet.

Irak følger modellen til det franske rettssystemet og har således en såkalt civil law basert på den napoleonske lovgivnin-

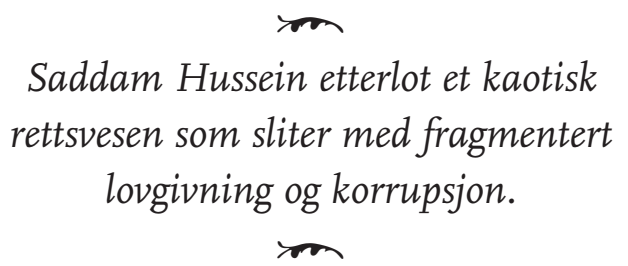

gen. Selve lovgivningen er et lappeteppe av lover utviklet under det britiske mandatet $i$ Egypt, ottomanske lover, og shari'a. Arbeidet med å effektivisere og oppdatere strafferettsystemet er således komplekst. Etter invasjonen i 2003 begynte The Coalition Provisional Authority (CPA) prosessen med å forberede ny lovgivning. Ifølge lederen for Shurarådet, som oversender lovforslag til ministerrådet før de legges frem for nasjonalforsamlingen, ble denne lovgivningen verken skrevet på arabisk eller tilpasset Iraks eksisterende lovgivning. Et annet problem er at Iraks grunnlov befester rettsvesenets selvstendighet, men overlater viktige og kontroversielle detaljer til lovgivningsprosessen. At grunnloven på dette punktet er vag er ikke overraskende. Der USA brukte sju år på å ferdigstille grunnloven, skulle Iraks vedtas i løpet av 
bare noen måneder. Grunnloven er også vag på punktene som gjelder regionalt selvstyre og fordelingen av naturressurser. Dette har skapt komplikasjoner for den nye oljeloven ettersom de ulike fraksjonene tolker grunnloven forskjellig.

Rettsvesenet i Irak mangler videre et regelverk for sine ansatte. Et slikt regelverk er ment å sikre integriteten til rettsvesenet og forhindre korrupsjon. I tråd med regelverket skal det etableres klageinstanser og utmåles straff for brudd på regelverket. I irakisk lov finnes det kun fragmenter av et slikt regelverk, mens det egentlig er behov for et samlet regelverk som hver enkelt dommer eller advokat kan referere til. Et annet trekk ved rettsvesenet som åpner for korrupsjon, er regler som i teorien er ment å sikre effektiv rettergang, men i praksis gjør systemet sårbart.

Ett slikt eksempel er en spesiell foreldelsesfrist for straffesaker. Ulike typer kriminalitet får ulike tidsfrister før saken må behandles i retten. Behandles ikke saken innen den gitte fristen, går den tiltalte fri, eller blir sittende i forvaring uten dom. Denne regelen er ment å forhindre køer av saker, men gir i praksis dommerne insentiver til å behandle de sakene det er mest lønnsomt eller minst farlig å behandle. ${ }^{\text {II }}$ Kapasiteten til rettsvesenet blir dessuten dårligere for hver uke som går. Irak har for øyeblikket rundt regnet 700-800 dommere, men trenger minst dobbelt så mange. Dommere befinner seg også på dødslistene til flere av militsene og opprørsbevegelsene og blir jevnlig drept. I tillegg har mange av de irakiske juristene som levde i eksil i Europa og USA og returnerte til Irak i 2003, reist igjen. Utdanning av nye dommere går sent, og kapasiteten til instansene som utdanner dem, er svært begrenset. Rettsvesenet har også blitt offer for sekterismen som fulgte av CPA sitt dekret nummer 2 som omhandlet de-Baathifisering i 2003. Mens kurderne opptrer med et nærmest selvstendig og parallelt system, består det øvrige irakiske rettsvesenet i hovedsak av shiaer. De-Baathifisering sørget for at nærmere 50 o०০ offentlig ansatte, hovedsaklig sunnier, mistet jobben. Dette medførte at virksomheten i departementene, domstoler, statlige bedrifter og andre instanser stanset opp. Dekretet om de-Baathifisering fulgte i kjølvannet av CPA-ordre nummer I som avsatte 250 000-300 000 av Saddam sine sikkerhetsstyrker og militære. Dette dekretet hadde store konsekvenser for opprøret, volden og politiet i Irak.

POLITIET

Politiet i Irak er gjenstand for korrupsjon, infiltrasjon og sekterisme og mangler kompetanse og kapasitet. Koalisjonens plan for det nye irakiske politiet var at det skulle følge en tradisjonell struktur. På nasjonalt plan skulle Irak ha en nasjonal etterretningstjeneste separat fra militær etterretning. Deretter skulle politiet på distrikts- og lokalplan deles inn i serious crimes units, med ansvar for organisert kriminalitet og alvorlig voldskriminalitet, og til slutt lokale politienheter som skulle står for håndhevningen av loven i forbindelse med mer dagligdagse lovbrudd. Målsettingen er god, men det er lite som tyder på at planen ble godt gjennomført.

I enkelte deler av Irak består politistyrken av opptil 80 prosent militsmedlemmer, kriminelle eller opprørere. ${ }^{22}$ Den største andelen av disse er igjen shiaer, ettersom sunniene ble ekskludert gjennom CPA-ordre nummer én og to. Da koalisjo- 
nen skulle etablere en ny politistyrke etter invasjonen, ble deler av opplæringen og treningen satt bort til private kontraktører. I mer enn ett tilfelle mottok ikke politistyrken mer enn noen få dagers trening og opplæring. Det verserer også en historie om at det nye treningsakademiet til politiet i Bagdad, som ble bygget av en privat kontraktør, er av så dårlig kvalitet at kloakken fra toalettene lekker inn i klasserommene. Det var koalisjonens militære styrker som hadde hovedansvaret for å etablere en ny politistyrke. Dette er problematisk ettersom dette ikke hører til militærets kjernekompetanse. Ifølge en koalisjonsansatt med politibakgrunn er det nye irakiske politiet lite annet enn en paramilitær organisasjon.

Politiet i Irak mangler både ustyr og kompetanse til å beskytte og tjene befolkningen. De færreste har mottatt grundig opplæring i hvordan man utfører en etterforskning. På den preventive siden kan politistyrken lite eller ingenting om hvordan den etablerer gode relasjoner til lokalbefolkningen og respekt for loven. På etterretningssiden står de svakt og er dermed dårlig rustet til å møte utfordringene den organiserte kriminaliteten representerer. Som tilfellet er med rettsvesenet, mangler også politiet et regelverk for sine tjenestemenn og -kvinner. Det har heller ingen klageinstanser eller noe effektivt internt etterforskningsorgan.

I Sør-Irak har man eksempler på politibrigader som sloss om kontrollen over områder relevante for smuglervirksomhet. Brigadene er lojale overfor partiene til for eksempel Sadr, Hakim eller det mindre omtalte Fadhilapartiet. I mer enn ett tilfelle har koalisjonsstyrker og lojale sikkerhetsstyrker måttet nedkjempe politiet de har trent. Internasjonale medier har presentert dette som tilfeller der irakisk politi gjenvant kontrollen over distriktet sitt fra militsene, mens det i realiteten var en intern maktkamp. De krigende partene i ulike deler av Irak representerer de forskjellige politiske og individuelle aktørene sentralt i Bagdad. Innenriksdepartementet har flere ganger uttalt at det skal renske politiet for kriminelle og militselementer, men dette har forblitt kosmetisk.

Hvordan sekterismen paralyserer effektive reformer i politiet ble ekstra tydelig i arbeidet med et grensekontrollprosjekt utarbeidet av UNODC i 2003 og oppdatert i 2006. Prosjektet hadde tilstrekkelig finansiering til å begynne implementeringen, men manglet irakiske myndigheter sitt samtykke og underskrift. Målet med prosjektet var å koordinere politi, tollvesen, kystvakt, militæret og etterretningen under en nasjonal grensekontrollplan. Videre måtte det skapes provisjoner under irakisk lov for grensekontrollsamarbeid med nabolandene. Prosjektet skulle implementeres i samarbeid med koalisjonsstyrkene som jobbet innen samme felt. Ifølge tjenestemenn i koalisjonen som jobbet med politiet, irakisk etterretning og militæret, ville tiltaket supplere deres aktiviteter godt. Prosjektet ble aldri underskrevet.

Det forelå aldri noen offisiell forklaring, men et hinder var mangelen på samarbeid mellom de ulike organene med ansvar for grensekontroll. Disse organene lå under fire ulike departement og kontorer, nemlig finans, justis, forsvar og statsministerens kontor. Departementene tilhører ulike poli-

Kurdisk kvinne i den irakiske byen Halabjah. 
babylon 10.7.3:babylon5 26-10-07 13:29 Side 153

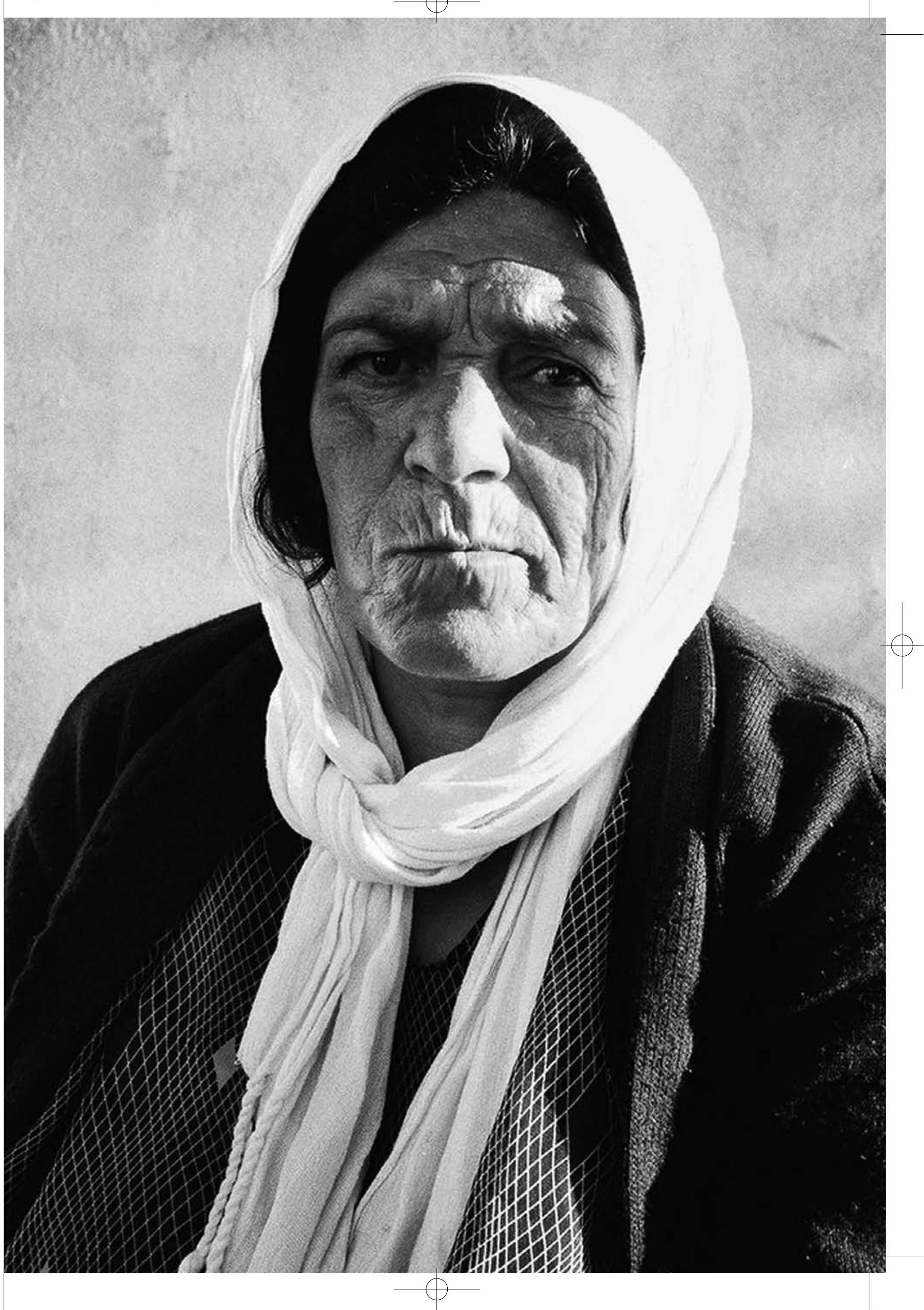


tiske partier som i neste rekke kontrollerer krigende grupper og militser som er engasjert i kriminell virksomhet lokalt.

\section{FENGSELSVESENET}

Fengselsvesenet i Irak er fragmentert og korrupt, og de ansatte mangler opplæring. I likhet med i politiet og rettsvesenet har heller ikke ansatte $i$ fengselsvesenet et regelverk å forholde seg til. Ansvaret for fengsler og forvaringsanstalter i Irak er delt mellom innenriks-, justis-, og arbeids- og sosialdepartementet. Innenriksdepartementet besitter institusjoner for pågrepne så vel som et ukjent antall hemmelige fasiliteter som antas å operere i grenseland eller regelrett utenfor loven. Justisdepartementet kontrollerer de vanlige fengslene, men har ikke ansvar for bygningene. Bygningene "eies" av arbeids- og sosialdepartementet som også har ansvaret for institusjonene for barn og ungdom. Årsaken til denne upraktiske inndelingen er uklar, men det kan tenkes at dette er et budsjettspørsmål. Ingen departementer liker å miste en del av porteføljen sin og dermed tape budsjettmidler.

Manglende administrasjon gjør at antallet innsatte i Irak er uklart og varierer fra 25 000-50 000. Det finnes heller ingen oversikt over hva folk sitter inne for, eller hvem, og hvor mange, som ikke er domfelt. Prosedyrer og regelverk er fragmentert og utilstrekkelig. Ansatte i fengselsvesenet har liten eller ingen opplæring og kjenner ikke til innsattes rettigheter. Soningsforholdene er elendige og bryter med internasjonale normer om tilmålt plass per fange, helsetjenester og atskilte fasiliteter for menn, kvinner og barn. Det finnes heller ingen instans som har til ansvar å ha overoppsyn med soningsforholdene, et internt kontroll- organ, eller en klageinstans. Det rapporteres jevnlig om tortur i fengslene. Politiet har tilgang til de innsatte $\mathrm{i}$ fengslene selv etter domfellelse. Rehabiliteringsaspektet ved fengsler er gjenstand for debatt, men dette fungerer ekstra dårlig der en innsatt ikke kan begynne å forsone seg med straffen fordi saken aldri avsluttes fra politiet sin side. Strafferettsystemet som helhet er dårlig finansiert. Ineffektivitet blant departementene og endemisk korrupsjon gjør at allokerte midler ikke når frem.

\section{Irak fra vondt til verre}

Kaoset i Irak er så komplett at det er vanskelig å besvare spørsmålet om hva som gikk galt uten å gå seg fullstendig bort. I spørsmålet ligger det også en implisitt felle idet det insinuerer at det fantes en måte å håndtere Irak riktig på. Liberal intervensjonisme og nasjonsbygging er geskjefter med forholdsvis korte og variable merittlister. Som gjennomgangen av noen aspekter ved strafferettsystemet viser, er nasjonsbygging tidkrevende finmekanikk.

Koalisjonen med USA i spissen begikk samme feil som franske og britiske koloniherrer før dem, de innså ikke at de sto overfor et organisert opprør før det var for sent. Påstandene Colin Powell la frem for FN sitt sikkerhetsråd da han argumenterte for invasjonen er blitt en selvoppfyllende profeti. Al-Qaida hadde ingen tilknytning til Irak, mens i 2007 har terrortaktikk utviklet i Irak blitt benyttet i Afghanistan, Somalia, Libanon, Algerie, Marokko og Skottland. Nabolandene har valgt side og stedfortredere i krigen i Irak, og er således allerede engasjert $i$ en regional krig. Spørsmålet videre er om det forblir en krig hvor Irak utgjør slagmarken for sted156 
fortrederne, eller om intensiteten vil øke og landene involveres mer direkte. For øyeblikket ser det ut til at det på et tidspunkt vil komme til større sammenstøt mellom de mange grupperingene. Da vil noen vinne og noen tape, og konturene av konflikten videre vil bli tydeligere. Tredelingen mange er så opptatt av er mer eller mindre reell, og spørsmålet dreier seg egentlig om hvorvidt den vil formaliseres. Kurdiske representanter sier selv at det internasjonale samfunnet ikke er modent for en ny og kurdisk nasjonalstat. Et Shiastan vil uansett forbli en konfliktsone hvor partene kjemper videre om ressursene. Et Sunnistan på sin side virker så komplisert at det er vanskelig å utrede for øyeblikket. Hvis poenget med en tredeling er å stabilisere landet, er man på villspor.

Forventningen Bush-administrasjonen skapte, var at blomstene skulle regne over soldatene i Bagdad, og at Midtøsten skulle få et demokratisk og liberalistisk eksempel til etterfølgelse. Hovedproblemet for irakere, koalisjonen, FN og andre involvert i den såkalte gjenreisningen er at det for øyeblikket ikke finnes noe å bygge på. Det finnes ingen effektiv myndighet $\mathrm{i}$ betydningen av en myndighet som styrer med integritet til det beste for den bredere befolkningen. Regjeringen har misbrukt legitimiteten den ble tilbudt i valget og har verken vilje eller kapasitet til å takle noen av Irak sine problemer. Koalisjonen og regjeringen deler den tvilsomme æren for at Irak er i ferd med å bli et utviklingsland. Det som er vanskeligst å forstå er hvordan et land som USA med all sin samlede kapasitet og ekspertise kunne gjøre så mange åpenbare feil. Den blinde ideologien og idealismen er kanskje det mest nærliggende svaret.
I Wickham, DeWayne: "Pin flip-flop tag on Bush, The Forum" I USA Today, http://www.usatoday.com/educate/ electiono4/article3o.htm

2 Se for eksempel Bellamy, Alex og Wiliams, Paul: "Who's Keeping the Peace? Regionalization and Contemporary Peace Operations" i International Security - Volume 29, Number 4, Spring 2005, pp. I57-I95.

3 Ulike aspekter ved dette skildres i: Chandrasekaran, Rajiv: Imperial Life in the Emerald City - Inside Iraq's Green Zone. Knopf, New York 2007; Parados, John: Hoodwinked - The Documents That Reveal How Bush Sold Us a War. The New Press, New York 2004; Shadid, Anthony: Night Draws Near - Iraq's People in the Shadow of America's War. Henry Holt, New York 2005; Weiner, Tim: Legacy of Ashes - The History of the CIA. Doubleday, New York 2007.

4 Se for eksempel: Van Creveld, Martin: The Transformation of War. The Free Press, New York I99I og Reno, William: Warlord Politics and African States. Lynne Rienner, Boulder, Colorado I998.

5 UNODC: Crime and Development in Africa, Juni 2005 tilgjengelig fra: http://www.unodc.org/pdf/African_report .pdf

6 FN-konvensjonen mot grenseoverskridende organisert kriminalitet definerer en organisert kriminell gruppe som en "strukturert gruppe på tre eller flere personer, som eksisterer i en viss tid, og som opptrer sammen med det mål å begå en eller flere alvorlige forbrytelser eller ett eller flere alvorlige lovbrudd fastsatt i samsvar med denne konvensjon, for direkte eller indirekte å oppnå en økonomisk eller annen materiell fordel". (http://www.regjeringen.no/ $\mathrm{nb} /$ dep/jd/dok/lover_regler/reglement/2002/FNs-kon vensjon-mot-grenseoverskridende-organisert-krimi nalitet.html?id=I07343)

7 Talen er tilgjengelig fra: http://www.unep.org/OurPlanet /imgversn/I53/annan.html

8 Cockburn, Patrick: "Opium: Iraq's deadly new export" i The Independent, London I4. september 2007.

9 Samtaler med Radhi Hamza al-Radhi på i Siracusa i september 2006 og i Amman I desember 2006.

IO Avisartikler som beskriver korrupsjon i Irak og CPI sitt arbeide er: Colvin, Marie: "Former Iraq minister denies theft of millions" i The Sunday Times, London II. mars 2007 og Glanz, James: " THE STRUGGLE FOR IRAQ; Oil Revenues Are in the Billions, But Iraq Is Failing to Spend Them" i New York Times, New York II. desember 2006.

II Samtaler med irakiske rettsinstanser 2006/2007.

I2 Samtaler med irakiske embetsmenn og koalisjonsansatte $2006 / 2007$. 